\title{
A MODEL OF THE SELECTION OF AN OPTIMAL RAILROAD ROUTE BY APPLYING THE MULTIPLE-CRITERIA ANALYSIS
}

\author{
Ljudevit Krpan, Siniša Vilke, Marin Milković
}

Original scientific paper

The problems of choosing an optimal solution for the position of the route of infrastructural facilities is present in most developed countries. The primary problem is the identification and objective consideration of all influencing factors. The aim of this paper is to show that with the application of multiplecriteria analysis, conclusions related to the evaluation and selection of the appropriate railroad route can be reached in the process of planning and design. This paper provides an overview of the possible consideration and evaluation of alternative railroad route solutions. To achieve the goal of research, a model of the selection of an optimal railroad route by using the multiple-criteria analysis has been set. The proposed theoretical model was applied for the selection of the railroad route that connects Rijeka, Koper, and Trieste.

Keywords: case study; multiple-criteria analysis; queuing system; railroad system; Rijeka-Koper-Trieste railroad line; traffic modelling

Model odabira optimalne trase željezničke pruge primjenom višekriterijske analize

Izvorni znastveni članak

Problematika odabira optimalnog rješenja smještaja trase infrastrukturnih objekata prisutna je u većini razvijenih država. Pritom je primarni problem prepoznavanja i objektivnog sagledavanja svih utjecajnih čimbenika. Cilj je ovoga rada pokazati kako se primjenom metode višekriterijske analize mogu dobiti zaključci vezani za vrednovanje i izbor odgovarajuće trase željezničke pruge pri postupku planiranja i projektiranja. U radu se daje pregled mogućeg sagledavanja i vrednovanja varijantnih rješenja trasa željezničke pruge. Za ostvarenje cilja istraživanja postavljen je model odabira optimalne trase željezničke pruge primjenom višekriterijske analize. Predloženi teoretski model primijenjen je za odabir željezničke trase koja povezuje Rijeku, Kopar i Trst.

Ključne riječi: prometno modeliranje; studija slučaja; sustav opsluživanja; višekriterijska analiza; željeznička pruga Rijeka-Kopar-Trst; željeznički sustav

\section{Introduction}

The research subject of this paper is the analysis of the possibility of applying the model of the optimization of the selection of a railroad route by using the process of the multiple-criteria ranking of variants. The analysis was tested on a concrete example of the analysis of the variants of the routes of the Rijeka - Koper - Trieste railroad line.

The aim of the paper is to show how railroad routes can be evaluated with the application of multiple-criteria analysis in the process of planning and design.

Considering the research subject, this paper sets a hypothesis which states the following: For the evaluation and selection of an optimal railroad route, it is optimal to apply the method of multiple-criteria analysis.

Documented making of decisions, which is one of the objectives of the evaluation process, is possible only if the spaces for intuitive decision-making that, as a rule, cannot give reliable results given the fact that intuition always has personal experience as a basis, are methodologically narrowed. It should be borne in mind that it is not only the experts who decide on the traffic infrastructure, but also the wider public, which therefore imposes an obligation to numerically express the greatest number of information.

It is a fact that investments in the traffic infrastructure are becoming more and more complex due to the impact of a large number of parameters on the performance of an investment and a highly variable environment in which the project is implemented. Therefore, through a practical example, after determining the variants of the possible solutions for the Rijeka - Koper - Trieste railroad line, in accordance with the methodology of the process of the multiple-criteria ranking of variants, the parameters of specific criteria within the focus groups of the evaluation criteria have been determined. In accordance with the sodefined criteria and appropriate weighting coefficients, a multiple-criteria analysis of the evaluation of variants has been carried out. The reliability and functionality of the proposed model has been proven through the conducted analysis.

Kosijer, M. et al. [1] have developed a methodology for the selection of the railroad route that is based on the methods of multiple-criteria decision-making. The adopted list of criteria in research consists of quantitativeeconomic, quantitative-technical, and qualitative criteria. The verification of the proposed methodology was conducted on the example of the selection of one of the four variants of the railroad route on the section of Corridor X, between the Inđija and Novi Sad stations.

Considering the fact that certain groups of criteria were expressed through quantitative units for the solving of the problems of the choice of the railroad route, and other through qualitative units, the method of multiplecriteria compromise ranking, VIKOR, was applied. This method focuses on the ranking and selection of an alternative in the presence of conflict criteria, and the solution that is chosen is the one that is the closest to the ideal solution, which is a so-called compromise solution on the basis of the adopted measure of distance.

The model for the selection of the railroad route set in this paper contains a smaller number of economic criteria and a larger number of traffic and eco-sociological criteria in relation to [1]. Moreover, the assessment and evaluation of individual criteria were conducted on the basis of a qualitative assessment by the experts; while in the model developed by Kosijer, M. et al., a combination of quantitative and qualitative assessment is applied. 


\section{The methodology of the multi-criteria analysis}

In the process of making the decision on the optimal space-traffic solution, it is necessary to define the criteria and benchmarks on the basis of which the evaluation of solutions is carried out and the best solution is selected. Based on the previous research of the problems of competitiveness and the evaluation of space-traffic solutions, it follows that so far, in the analysis and selection of an optimal solution, the chosen approach was to give absolute priority to the economic criteria in the process of traffic planning and decision-making. Due to the need for a comprehensive research of the problems of valorization and the competitiveness of the traffic system, it is necessary to have an approach that is not limited to the analysis of certain aspects, but takes into account the simultaneous effect of a number of different aspects, i.e. the criteria that determine the possibility of valorization. One such approach is a method that refers to multiple-criteria optimization, which involves the selection of the optimal solution compared to the simultaneous effect of a number of different criteria. With the development of the modern procedures of selecting a solution, the consideration of solutions through a larger number of criteria (conditioned by the development of the society) has been enabled. In traffic planning, those can be the environmental, social, and traffic safety criteria. [2]

The selection of the criteria for deciding on the route of inland traffic infrastructure is a complex and sensitive process since the final decision depends on the purpose and possibility of evaluation. Moreover, the determining of the value scale requires special attention considering the fact that all the output values should be reduced to a common physical quantity.

For the possibility of a comprehensive valorization of individual solutions, an approach that takes into account the simultaneous effect of a number of different criteria is imposed. The approach that involves the ranking of individual variants and the selection of an optimal solution in relation to the simultaneous effect of a number of different criteria is provided by the method of a multiple-criteria ranking of variants. [3] The purpose of the ranking of variants is the narrowing of the space of decision-making and the quantified presentation of facts that are important in the decision-making process. The multiple-criteria ranking is especially important when making decisions about the choice of an optimal variant from a set of variants which differ depending on the adopted criteria.

Each multiple-criteria problem consists of a number of different, and in most cases conflicting, criteria that may be of different importance for the decisionmaker. Most methods for the selection of the best variant, i.e. generally the methods for multiple-criteria decisionmaking require information on the relative importance of each criterion. [4] Assessing the importance of the criteria must be done by the decision-maker, or it is determined based on the opinion of a group of experts.

The general features of a multiple-criteria problem, which vary in relation to single-criteria problems, are reflected in the presence of the following elements: [5]

- more criteria (the objective function, the criteria function) for decision-making,
- more alternatives (solutions) for the selection,

- the process of the selection of a single solution.

Multiple-criteria optimization is a useful tool for the presenting of an optimal solution with defined assumptions. One of the important prerequisites for achieving the desired effects of management and decision-making is making quality decisions to solve the problem at all stages. Even more so because in practice, in the selection of an optimal variant in traffic planning and design, traffic experts are not the only ones who participate. An important role is played by officials at various levels of decision-making who do not need to have specialized professional knowledge. Therefore, the decision-maker is typically a natural or legal person who is responsible for the adoption of the final optimal solution or variant. Their primary role is to define the criteria and the structure of the preference, and, with the help of experts, to select the final variant. The structure of the preference of the decision-maker is usually based on the technical, economic, social, and political criteria. If the structure of the preference is known before the process of optimization, the decision-making process is relatively simple, and in the case of changes in the structure during the procedure, the process becomes much more complex. [6]

A prerequisite for the implementation of the method of multiple-criteria analysis in traffic planning and design is to determine the combination of the selected criteria, the importance of the criteria, and the function of the criteria whose changes can help perceive their influence on the selection of an optimal traffic route. Since preferences are seen as a subjective factor, by defining the importance, i.e. the weighting coefficients of criteria, what is taken into account are the wishes and intentions of the decision-maker. When analyzing the use of specific criteria in the procedures of traffic planning and design, it becomes clear that there are no dominant criteria, but their importance varies according to each individual problem.

A prerequisite for objective decision-making is an objective presentation of facts. In this respect, it is very important to adhere to the following principles:

- Prior to the development of variant solutions, it is necessary to implement a social verification of the building objectives and evaluation criteria. In this way, an impartial and equal treatment of competing variants is ensured.

- To consider all the real variants, i.e. to not narrow down the creative possibilities of planning teams. The comparability of variant solutions should be provided with unique methodological and technological processes in the process of planning.

- Through the comparison of variants according to their differences, i.e. to determine with the highest reliability the relative value of each tested variant (e.g. in relation to the current situation, the so-called zero variant). Thus, based on the same settings, the absolute value of an indicator is of secondary importance.

- For all variant solutions there must be the same applicable planning period in which positive and negative effects are defined. In other words, it makes no sense to compare variants that are a short-term 
solution with a variant that represents a long-term or permanent solution.

- To consider all the positive and negative effects of building, no matter where they occur, and in whose interest they are. For example, with the construction of a route, users achieve a higher level of safety, shorter travel times, etc., while residents along the route feel the consequences through an increase in air pollution, noise, and the like.

Specific problems of the selection of a potential location and/or infrastructural facility route require the collection and analysis of a wide variety of data and include the work of experts from various fields. It is particularly important to include the public in the selection of potential alternatives because ultimately the decision-making process shifts from the institutional level and the making of documents to the level of project implementation in which the participation of the public also affects the final result of the project.

\subsection{The application of the multiple-criteria analysis in traffic planning and design}

In order to avoid an uncontrolled and uncritical approach to the planning of traffic systems, it is necessary to define the criteria for the evaluation of the proposals of variant solutions when planning the traffic network. Based on the established range of priorities evaluated according to the explicitly stated, defined, and adopted criteria, the optimal elements of the traffic system are determined, and a clear basis for the definition and development of a space-traffic model of the designated area is created.

The application of the method of multiple-criteria optimization is acceptable under the following assumptions:

1) a detailed defining of the criteria and an objective evaluation of their importance,

2) a careful development of variant solutions, i.e. an equal level of the processing of criteria for each variant, on the basis of which a mutual comparison of variants in relation to the fulfilment of certain criteria is possible,

3) an evaluation of all variants according to the adopted criteria.

It is important to point out that according to their importance, the criteria are perceived as eliminatory and parallel.

\subsubsection{The eliminatory criteria of the evaluation of space- traffic solutions}

The eliminatory criterion defines the value or the value range of a certain criterion with which the location/route is not suitable. The disadvantage of the location cannot be compensated by an increased quality of the location/route according to other criteria. That is, if the location does not meet the desired state according to the observed criterion, it is unacceptable regardless of the other criteria. The main objective of the selection and application of eliminatory criteria is to eliminate as much of the interest area as possible, and to simplify through that the process of finding and evaluating potential locations. Therefore, the list of eliminatory criteria does not have to be complete. It is desirable to apply only the criteria that will eliminate the largest area. The selection of eliminatory criteria should be given maximum attention. If they are badly selected, too strict, or if their application is based on insufficient or problematic data and information, it is possible that an objectively good location be rejected at the very beginning. If this happens, that is a fatal error in the process of the selection of offered alternatives. In contrast, if after the application of eliminatory criteria, the objectively inadequate locations/routes/corridors pass to the next stage of the process, the damage is significantly less or inexistent. Such locations will either way, sooner or later, be eliminated. When considering the choice and adoption of eliminatory criteria, the aspects that significantly affect or may affect the choice of location/route are taken into account:

1) the acceptability of the location with respect to the impact on the environment during the construction of the planned facility and its operational times,

2) technical and technological aspects,

3) safety aspects - the risks of extreme external influences on the planned facility, whether they are natural (earthquake, flood, etc.) or caused by human activities (fire, explosion, rush of planes, the breaking of a dam, etc.),

4) the economy of construction and/or operating of the facility.

By using eliminatory criteria, the areas that are not acceptable by at least one eliminatory criterion are rejected. After the application of eliminatory criteria, the potential alternatives in an area that is not eliminated are determined, and are analyzed by using the comparative criteria.

\subsubsection{The comparative criteria of the evaluation of space traffic solutions}

Comparative criteria are the rules for the evaluation of potential locations, and they usually appear in the form of requirements to achieve a certain objective. After the application of eliminatory criteria, the criteria for the comparison of the remaining locations are determined. In determining the comparative criteria, one should strive that they be independent of each other and that they include all the differences between the evaluated locations: traffic-technical-technological, environmental and safety, socio-political, and economic differences. It should be noted that the selection of criteria depends on the area of interest for the selection of the location. If according to a certain criterion there are no differences between the processed locations, then that criterion can be omitted. Thus, the criteria that are not applicable in a given area of interest can also be omitted.

In the relevant group of comparative criteria, the following can certainly be counted in: the traffic-technical criterion, the railroad line throughput criterion, phase feasibility criteria, environmental acceptability criteria, the criteria of a spatially acceptable design, the traffic 
safety criterion, the geological and seismological criterion, the energy efficiency criterion, the criteria for the compliance of international standards, the criterion of the developmental potential of the region, rationality criteria, and others.

\subsection{The theoretical determinants of the PROMETHEE method}

Considering the fact that with most multiple-criteria problems there is generally no best solution, the problem boils down to defining a set of good systems, locations, projects, traffic routes, etc. One of the most important methods of multiple-criteria optimization is the PROMETHEE method.

The main settings on which the PROMETHEE (Preference Ranking Organization METHod for Enrichment Evaluations) method for a multiple-criteria ranking of variants is based on are the following: [7]

1) The expansion of the notion of criteria.

2) The evaluation of the relation of a "higher rank".

3) The use of the relation of a higher rank.

The expansion of the notion of criteria is based on the expansion of the criteria by introducing the preference function, which gives the preference of the decisionmaker for the variant $a$ in relation to the variant $b$. The preference function is defined for each criterion in particular, its value ranges between 0 and 1 , and it represents the probability of the realization of the project according to a particular criterion. The smaller the value of the preference function, the greater the indifference of the decision-maker; and vice versa, the closer the value of the function is to 1 , the greater his preference. In the case of strict preference, the value of the preference function is 1.

The criterion $g$, a real function from the set of possible variants $A$ in $\mathfrak{R}$, is such that the comparison of alternatives, i.e. variants $a$ and $b$ is based on the comparison of their estimated values according to the criteria, $g(a)$ and $g(b)$.

The associated preference function $P(a, b)$, from $(a)$ in relation to $(b)$, is defined according to the equation:

$$
P(a, b)=\left[\begin{array}{ll}
0 & \text { if } g(a) \leq g(b) \\
p[g(a), g(b)] & \text { if } g(a)>g(b)
\end{array} .\right.
$$

For specific cases, it is possible to choose the $p$ function of the following type

$$
p[g(a), g(b)]=p[g(a)-g(b)]
$$

depending on the difference between the values $g(a)$ and $g(b)$.

In order to determine the area of indifference around $g(b)$, the following is indicated:

$$
x=g(a)-g(b)
$$

and the function $H(x)$ is graphically illustrated so that:

$$
H(x)=\left[\begin{array}{ll}
P(a, b) & x \geq 0 \\
P(b, a) & x \leq 0 .
\end{array}\right.
$$

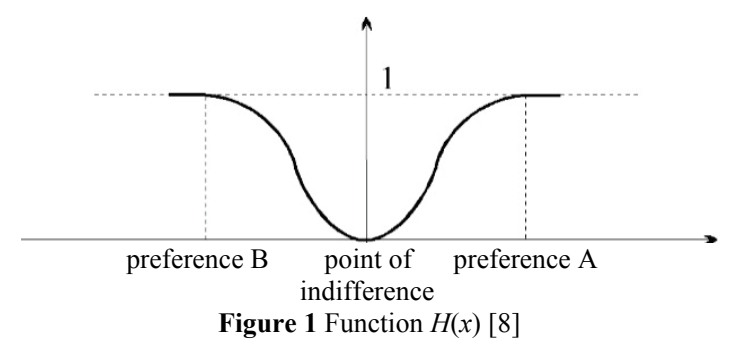

On the basis of research, the authors of this method determined that the majority of cases that occur in practical application are covered by six different types of criteria functions, and that the decision-maker should define two parameters at most. Those six types of criteria can be used when solving the majority of the real problems of multiple-attribute decision-making.

For the choice of the optimal railroad route in the set model, all evaluation criteria are defined as the usual criteria or as the criteria for which it is not necessary to define additional parameters that clearly specify the preference function.

The application of criteria shaped in such a way allows the construction of the estimated relation of a "higher rank".

The preference functions $P_{i}(a, b)$ are defined for each criterion $i=1, \ldots, n$ so that the multiple-criteria preference index is defined by the following equation:

$\pi(a, b)=\frac{1}{n} \sum_{i=1}^{n} P_{i}(a, b)$

where $n$ - the number of criteria.

This index provides a measure of preference $a$ over $b$, when all the criteria are simultaneously taken into consideration; the closer to 1 that the index is, the greater the preference. The Eq. (5) assumes that all criteria are of the same importance. As in most cases this is not so, what is introduced is the weighted preference index, where appropriate weight is given to each criterion.

If preference functions $P_{i}(a, b)$ and the weights of the criteria $W_{j}$ are defined for each criterion $j=1, \ldots, k$, then for every $a, b \in A$, and the multiple-criteria preference index is defined as:

$\pi(a, b)=\frac{\sum_{i=1}^{n} W_{i} P_{i}(a, b)}{\sum_{i=1}^{n} W_{i}}$,

where $W_{i}$ - the weight of the criteria.

Using the relation of a higher rank implies a specific use of the estimated relation of a "higher rank", especially in the case when variants have to be ranked from the best to the worst. The PROMETHEE I procedure makes the partial ranking of variants possible, i.e. the ranking in which there is a possibility for different variants to be of the same rank, and in this way certain ranks are left unused. Full ranking, in which each individual variant is 
differently ranked depending on the preference function, can be realized through the PROMETHEE II procedure. For practical use in traffic planning and design, PROMETHEE II is the most used method since it enables the determining of an order. On the basis of importing precise data, what this method makes possible is a partial and complete ranking of a large number of variants with respect to a larger number of criteria.

\section{A model for the selection of a railroad route}

A universal unambiguous list of objectives and criteria cannot be established since each traffic solution, in addition to the general criteria (e.g. costs, environmental impact, etc.), must comply with specific criteria that are primarily defined by certain physical characteristics. The specifics of the field can be more directly expressed through the relative importance of the criteria (the "weight" of criteria). During the work on the space-traffic study, decisions are continuously made through a more or less formalized matrix of the weight of criteria. Such a matrix of the weight of criteria is undoubtedly the product of a thought process, is of limited range depending on the creative possibilities of planners to consider all the relevant aspects of the problem and to get rid of the possible subjective influences. Variant solutions of space-traffic studies are adopted through the decision-making process with the direct participation of the public and the broadest sociopolitical structures. Therefore, it is very important to verify the position on the hierarchy of the objectives and criteria, and at the same time to clearly define the social commitment on the importance of each of the adopted criteria.

Due to the fact that the quality of the implemented procedure of the selection of the best variant of the railroad line and the accuracy of the final decision directly depend on the quality of the selected criteria, it is extremely important to do well in determining the criteria and measures according to which the implementation of optimization is carried out. Experts must participate in defining the criteria in order to ensure that the assessment of the importance of criteria does not succumb to the subjective approach.

The criteria for the evaluation of the railroad traffic route can be divided according to a number of different ways. The most important way is the one that makes a difference between the variants of the evaluation of criteria, and with respect to that, there are two different sets of criteria:

- a set of criteria that is evaluated on the basis of concrete, exact, and quantitatively expressed data, and

- a set of criteria that is evaluated on the basis of the subjective opinion of researchers who are assumed and required to have sufficient knowledge of the problems and criteria that they will be evaluating.

To set up a model for the evaluation and selection of the railroad route, the criteria and focus sets of criteria have been defined, and their evaluation, i.e. the assigning of weighting coefficients has been performed.
Table 1 Sets of criteria and the criteria for evaluation and their importance of the models for the selection of a railroad route (according to [9])

\begin{tabular}{|c|c|c|c|}
\hline \multirow{2}{*}{\multicolumn{2}{|c|}{$\begin{array}{c}\text { Set of } \\
\text { Criteria }(\%) \\
\end{array}$}} & \multicolumn{2}{|l|}{ Criteria } \\
\hline & & Full name & Value $(\%)$ \\
\hline \multirow{5}{*}{ 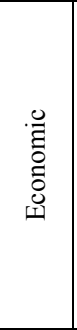 } & \multirow{5}{*}{21} & The costs of the construction of the route & 27 \\
\hline & & $\begin{array}{l}\text { Activation/deactivation of production- } \\
\text { business zones next to the built route }\end{array}$ & 13 \\
\hline & & $\begin{array}{l}\text { The costs of management and } \\
\text { maintenance }\end{array}$ & 25 \\
\hline & & $\begin{array}{c}\text { The influence on the land depreciation of } \\
\text { the local population }\end{array}$ & 16 \\
\hline & & $\begin{array}{c}\text { The development of tourism and other } \\
\text { economic activities in the zone of } \\
\text { influence }\end{array}$ & 19 \\
\hline \multirow{6}{*}{ 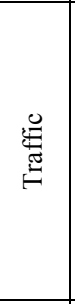 } & \multirow{6}{*}{29} & $\begin{array}{l}\text { The possibility of including the route in } \\
\text { the city railroad system, and integrating it } \\
\text { in the intermodal traffic system }\end{array}$ & 17 \\
\hline & & $\begin{array}{l}\text { The proximity of passenger aprons with } \\
\text { regard to other traffic terminals }\end{array}$ & 10 \\
\hline & & The capacity of the railroad line & 20 \\
\hline & & Train journey duration & 16 \\
\hline & & Reliability and maximum train speed & 14 \\
\hline & & Transport safety & 23 \\
\hline \multirow{3}{*}{ 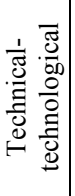 } & \multirow{3}{*}{12} & $\begin{array}{l}\text { The technical complexity of the } \\
\text { construction of the route }\end{array}$ & 44 \\
\hline & & $\begin{array}{l}\text { The geological-geotechnical conditions of } \\
\text { the terrain }\end{array}$ & 26 \\
\hline & & The availability of space (free land) & 30 \\
\hline \multirow{6}{*}{ 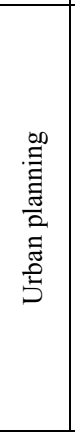 } & \multirow{6}{*}{18} & $\begin{array}{c}\text { The formative influence of the route to the } \\
\text { new image of the area (visual landscape } \\
\text { impact) }\end{array}$ & 26 \\
\hline & & $\begin{array}{c}\text { Damage to the relief and the possibilities } \\
\text { of recovery }\end{array}$ & 15 \\
\hline & & $\begin{array}{l}\text { Attracting other activities that endanger } \\
\text { the geomorphological features of the area }\end{array}$ & 14 \\
\hline & & $\begin{array}{l}\text { The impact on the development of the } \\
\text { potential in urban planning }\end{array}$ & 17 \\
\hline & & $\begin{array}{l}\text { The impact on phase development and the } \\
\text { conversion of space }\end{array}$ & 12 \\
\hline & & $\begin{array}{c}\text { The layout occupancy of the land area of } \\
\text { particular variant solutions }\end{array}$ & 16 \\
\hline \multirow{10}{*}{$\begin{array}{l}\bar{T} \\
.00 \\
00 \\
0 \\
0 \\
0 \\
0 \\
0 \\
0 \\
0 \\
0 \\
0\end{array}$} & \multirow{10}{*}{20} & Environmental impact & 17 \\
\hline & & Spatial impact & 10 \\
\hline & & The influence of noise & 9 \\
\hline & & $\begin{array}{l}\text { The influence of meteorological } \\
\text { conditions (wind, etc.) }\end{array}$ & 6 \\
\hline & & $\begin{array}{l}\text { The influence of the route in the zones of } \\
\text { water protection }\end{array}$ & 10 \\
\hline & & Conservation restrictions & 8 \\
\hline & & $\begin{array}{c}\text { Protected areas and habitat (ecological } \\
\text { network) }\end{array}$ & 13 \\
\hline & & $\begin{array}{l}\text { The density of housing at a distance of } \\
100 \mathrm{~m} \text { along the planned route } \\
\text { (influence on the population) }\end{array}$ & 11 \\
\hline & & The distance from tourist zones & 8 \\
\hline & & The distance from populated areas & 8 \\
\hline
\end{tabular}

For the purpose of the selection of the railroad route and the purpose of the application of the method of the multiple-criteria analysis, the selection of criteria was carried out in accordance with the information received from a larger number of experts in the field of traffic planning and design. The framework of the defined model was applied in the preparations for the making of the multiple-criteria analyses of the railroad variants at the Rijeka traffic junction while preparing the Space and Traffic Integral Study of the Primorje-Gorski kotar County and the City of Rijeka. [8] The criteria for the evaluation of the railroad route are divided into five focus groups. By dividing the themed set of criteria into less complex components, a better access of the process of the 
multiple-criteria ranking of variants is enabled, as well as the possibility of analyzing the results and drawing conclusions on the evaluation of certain routes.

The model for the selection of the railroad route which includes the focus groups of criteria and the criteria for evaluation and their assigned weighting coefficients (of importance) is shown in Tab. 1.

The importance of the focus groups of criteria is mutually compared, while the weighting coefficients are normalized so that their sum is $100 \%$. Furthermore, the weighting coefficients of the criteria within a certain focus group of criteria are normalized so that the total possible sum within each group of criteria is $100 \%$.

The proposed model for the selection of the railroad route will be applied to rank the variant solutions of connecting the North Adriatic ports of Rijeka, Koper, and Trieste by a high efficiency railroad.

\section{The application of the multiple-criteria analysis for the selection of the Rijeka-Koper-Trieste railroad route}

To optimize the selection of the route of the railroad traffic corridor that will connect Rijeka, Koper, and Trieste, a process of a multiple-criteria ranking of varieties has been applied, the so-called method PROMETHEE II, and a computer program for multiplecriteria programming "Visual PROMETHEE".

The multiple-criteria analysis for the selection of the route of the railroad corridor was conducted in four phases in the following order:

1) the determining of variant solutions for the railroad route,

2) the evaluation of particular variants in accordance with the set criteria and sub-criteria,

3) the comparison and ranking, i.e. the evaluation of particular variants,

4) the making of the decision on the optimal variant solution for the corridor

Among the expected route corridors, seven variants with several sub-variants stand out. After an elaboration of the technical elements, an analysis of investment costs, analysis of significant environmental segments, and with the help of the elimination method and expert assessment, four variant solutions have been chosen for a multiplecriteria analysis, and for each of them basic technical parameters have been determined: [10]

Variant 1: Jurdani station - Pivka - Divača station;

Variant 1A: Jurdani station - Pivka - Divača station;

Variant 2: Jurdanistation - Divača station;

Variant 3: Jurdani station - junction to the new Koper - Divača railroad line

The research subject is the Rijeka (Jurdani) - Trieste (Opiccina) railroad section. Starting from the Divača station, there are plans for the reconstruction, i.e. construction of a new double-track railroad to Trieste and Ljubljana. Those corridors have been assumed for multiple-criteria ranking, and new routes from Rijeka are planned so that there is a connection to the planned railroad line. By connecting the selected variant from Rijeka to Divača, and by creating a new connection to Trieste and Koper, what is ensured is an interconnection between the ports of Rijeka, Trieste, and Koper, and their connection to the sixth corridor of the TEN-T network..

By using computer software, an optimal railroad land traffic route between the North Adriatic ports of Rijeka, Koper, and Trieste will be selected, and the importance of a certain set of criteria, the criteria, and the values of the attributes of individual criteria for the three chosen variants will be used as input data.

\subsection{An analysis and evaluation of alternative railroad route solutions}

In order to analyze the four variants and properly evaluate them, they begin at the same point at the Jurdani station. In Fig. 2, an overview of railroad route variant solutions is presented.

The main technical-technological features of the planned facilities on the railroad line are shown in Tab. 2 for Variant 1, in Tab. 3 for Variant 2 and in Tab. 4 for Variant 3, respectively. The length of the route according to Variant 1 is $35,90 \mathrm{~km}$ long, and it stretches from the Jurdani station through Ilirska Bistrica to the Pivka station. Taking into account the coupling portion of the railroad from Pivka to Divača as the end point of all variants whose length will after the extension/reconstruction amount to about $16 \mathrm{~km}$, the total length of the route is approximately $51,70 \mathrm{~km}$. The railroad route passes north of Šapjane, and then enters the largest tunnel on the route, the total length of $5463 \mathrm{~m}$, crossing the state border between Croatia and Slovenia. The route then bypasses Ilirska Bistrica on whose bypass a new station and connection to the existing railroad route before the station are planned. The route continues further towards the north, following the corridor of the existing railroads much as possible because of the required minimal horizontal elements.

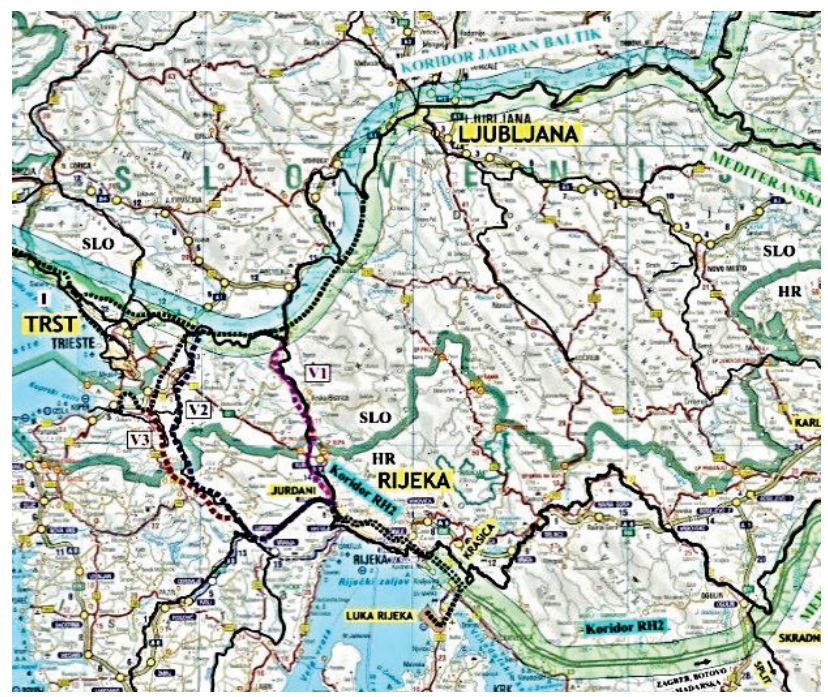

Figure 2 A clear overview of the analyzed variant railroad routes [10]

At the Pivka station, the connection to the existing Divača - Pivka - Ljubljana railroad line is planned.

Through that railroad line, a railroad connection between Rijeka and Trieste and Koper is planned via the new Divača - Koper line. The end of the route is at the Postojna station. 
The last 12 kilometers of the route include a series of viaducts of which two are the longest, Viaduct 5 with the length of $3677 \mathrm{~m}$ and Viaduct 7 with the length of 4294 $\mathrm{m}$. That is the part where the route takes a rise of 12 $\mathrm{mm} / \mathrm{m}$, reaching a maximum height of 580 meters above sea level in order to allow a connection to the existing Pivka - Divača railroad line.

Before the entrance to the Pivka station, it is possible to provide a triangle for a connection to the existing railroad line to Divača, in the second stage of phased construction.

Variant 1A bypasses the settlements north of Jurdani through a long tunnel, and with the necessary geometry corrections uses a part of the existing railroad line and also ends at the Pivka station.

Table 2 The length and share of the facilities on the route of Variant $1[10]$

\begin{tabular}{|l|r|}
\hline The overall length $(\mathrm{m})$ & 35857 \\
\hline The length of bridges and viaducts $(\mathrm{m})$ & 11559 \\
\hline The length of tunnels $(\mathrm{m})$ & 7741 \\
\hline The length of facilities $(\mathrm{m})$ & 19300 \\
\hline$L_{\text {net }}(\mathrm{m})$ & 16557 \\
\hline The share of bridges and viaducts on the route $(\%)$ & 32,24 \\
\hline The share of tunnels on the route $(\%)$ & 21,59 \\
\hline The overall share of facilities on the route $(\%)$ & 53,82 \\
\hline Route net $(\%)$ & 46,18 \\
\hline
\end{tabular}

The railroad route of Variant 2 extends from the Jurdani station over Lupoglava to the Divača station.

Table 3 The length and share of the facilities on the route of Variant $2[10]$

\begin{tabular}{|l|r|}
\hline The overall length $(\mathrm{m})$ & 64320 \\
\hline The length of bridges and viaducts $(\mathrm{m})$ & 6564 \\
\hline The length of tunnels $(\mathrm{m})$ & 28908 \\
\hline The length of facilities $(\mathrm{m})$ & 35472 \\
\hline$L_{\text {net }}(\mathrm{m})$ & 28848 \\
\hline The share of bridges and viaducts on the route $(\%)$ & 10,21 \\
\hline The share of tunnels on the route $(\%)$ & 44,94 \\
\hline The overall share of facilities on the route $(\%)$ & 55,15 \\
\hline Route net $(\%)$ & 44,85 \\
\hline
\end{tabular}

The total route length is $64,32 \mathrm{~km}$, of which $35,4 \mathrm{~km}$ is located on the territory of the Republic of Croatia and the remaining $28,92 \mathrm{~km}$ on the territory of the Republic of Slovenia.

The planned route of the railroad line commences at the existing Jurdani station and stretches through the Ćićarija tunnel, the longest facility on the route (total length of 15574 meters), arriving to the existing Lupoglav station on the Istrian side at 400 meters above sea level.

From Lupoglav station, it is possible, with a smaller deviation, to ensure a direct connection to the existing railroad line to Pula.

The route then leads through the existing valley by climbing towards Tunnel 2, the total length of $6600 \mathrm{~m}$, to the plateau above Buzet at the altitude of about 500 meters above sea level.

Before the entrance to the tunnel, Viaduct 3, the length of $1022 \mathrm{~m}$, is planned.

After leaving the route from Tunnel 2, the route leads to the altitude of about 480 meters above sea level to about 510 meters above sea level until the entrance to the Republic of Slovenia.

In this part of the route, a construction of Viaduct 4, the length of 2761 meters, and Tunnel 2, the length of 1754 meters, has been planned, as well as a climb to the Prešnica station which is located at an altitude of about 515 meters above sea level, where a connection with the existing railroad network (Divača - Koper/Buzet - Pula) is planned.

At the very end of the station, the route is located in Tunnel 4, the length of $1689 \mathrm{~m}$.

The route then extends to the north, east of Kozina, on whose section a construction of Viaducts 5 and 6 (the lengths of 740 and 476 meters, respectively) is planned. The route then descends towards the Divača station, passing Tunnel 5, the length of 3000 meters, Viaduct 7, the length of 270 meters, and Viaduct 8, the length of 800 meters.

The route ends by bypassing a populated part of Divača and by connecting itself to the station at the elevation of 435 meters above sea level.

The total length of the planned railroad line according to Variant 3 is $50,3 \mathrm{~km}$, of which $38,5 \mathrm{~km}$ is located on the territory of the Republic of Croatia and the remaining $11.8 \mathrm{~km}$ is on the territory of the Republic of Slovenia.

The route extends from the Jurdani station over Lupoglava to Črni Kal, a junction on the new Koper Divača railroad line.

Table 4 The length and share of the facilities on the route of Variant $3[10]$

\begin{tabular}{|l|r|}
\hline The overall length $(\mathrm{m})$ & 50329 \\
\hline The length of bridges and viaducts $(\mathrm{m})$ & 16187 \\
\hline The length of tunnels $(\mathrm{m})$ & 20116 \\
\hline The length of facilities $(\mathrm{m})$ & 36303 \\
\hline$L_{\text {net }}(\mathrm{m})$ & 14026 \\
\hline The share of bridges and viaducts on the route $(\%)$ & 32,16 \\
\hline The share of tunnels on the route $(\%)$ & 39,97 \\
\hline The overall share of facilities on the route $(\%)$ & 72,13 \\
\hline Route net $(\%)$ & 27,87 \\
\hline
\end{tabular}

According to the project, after the existing Jurdani railroad station, the route of this variant includes the construction of a tunnel through Ćićarija. The total length of the tunnel will be 15920 meters.

After arriving at the Lupoglav station at an altitude of about 400 meters above sea level, the route descends through an indented terrain through three viaducts and runs northeast from Buzet. Those viaducts are respectively Viaduct 2, the length of 4272 meters, Viaduct 3, the length of 1669 meters and Viaduct 4, the length of 5144 meters.

Through the territory of the Republic of Slovenia, the route first goes through a hilly area, then passes through two tunnels, and then through a valley via Viaduct. The total length of the route is 4834 meters.

The economic criteria $\mathrm{C} 1$ and $\mathrm{C} 3$ are expressed quantitatively in accordance with the estimated financial resources by experts according to [10]. For the criteria $\mathrm{C} 5$ and $\mathrm{C} 6$, the units of yes/no criteria are used, while for the ecological-sociological criteria C21, C25, and C27, input parameters were obtained from GIS (Geographic Information System), which was designed specifically for this multiple-criteria analysis. Appropriate parameters 
according to a rating scale from 0 to 10 were assigned to other criteria. Furthermore, a corresponding object function, i.e. its minimum and maximum was assigned to each criterion.

\begin{tabular}{|c|c|c|c|c|c|c|c|}
\hline \multirow{2}{*}{\multicolumn{2}{|c|}{$\begin{array}{c}\text { Set of } \\
\text { Criteria (\%) }\end{array}$}} & \multirow{2}{*}{$\begin{array}{c}\text { Criteria } \\
\text { Mark }\end{array}$} & \multirow{2}{*}{$\begin{array}{c}\text { Unit/ } \\
\text { Object } \\
\text { function }\end{array}$} & \multicolumn{4}{|c|}{ Variant } \\
\hline & & & & I & Ia & II & III \\
\hline \multirow{5}{*}{$\begin{array}{l}.0 \\
\Xi \\
0 \\
0 \\
0 \\
\text { ப̇ }\end{array}$} & \multirow{5}{*}{21} & $\mathrm{C} 1$ & $\begin{array}{l}\text { Mil } \\
\text { EUR } \\
\text { Min }\end{array}$ & 1366 & 1449 & 1738 & 1976 \\
\hline & & $\mathrm{C} 2$ & $\begin{array}{l}\text { Rating } \\
\text { Min }\end{array}$ & 0 & 0 & 0 & 0 \\
\hline & & C3 & $\begin{array}{c}000 \\
\text { EUR } \\
\text { Min }\end{array}$ & 1639 & 1679 & 2941 & 2301 \\
\hline & & $\mathrm{C} 4$ & $\begin{array}{c}\text { Grade } \\
\text { Min }\end{array}$ & 4 & 5 & 8 & 10 \\
\hline & & C5 & $\begin{array}{c}\text { Yes/No } \\
\text { Max }\end{array}$ & Yes & Yes & No & No \\
\hline \multirow{6}{*}{ 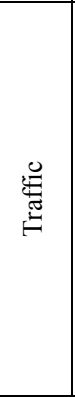 } & \multirow{6}{*}{29} & C6 & $\begin{array}{c}\text { Yes/No } \\
\text { Max }\end{array}$ & Yes & Yes & Yes & Yes \\
\hline & & C7 & $\begin{array}{c}\text { Grade } \\
\text { Min } \\
\end{array}$ & 7 & 7 & 5 & 5 \\
\hline & & $\mathrm{C} 8$ & $\begin{array}{l}\text { Grade } \\
\text { Min }\end{array}$ & 7 & 8 & 7 & 8 \\
\hline & & C9 & $\begin{array}{l}\text { Grade } \\
\text { Min }\end{array}$ & 6 & 6 & 8 & 6 \\
\hline & & C10 & $\begin{array}{l}\text { Grade } \\
\text { Min } \\
\end{array}$ & 5 & 6 & 6 & 8 \\
\hline & & C11 & $\begin{array}{l}\text { Grade } \\
\text { Min }\end{array}$ & 6 & 5 & 7 & 9 \\
\hline \multirow{3}{*}{ 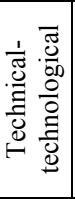 } & \multirow{3}{*}{12} & C12 & $\begin{array}{l}\text { Grade } \\
\text { Min }\end{array}$ & 3 & 3 & 2 & 6 \\
\hline & & C13 & $\begin{array}{l}\text { Grade } \\
\text { Min }\end{array}$ & 0 & 0 & 0 & 0 \\
\hline & & $\mathrm{C} 14$ & $\begin{array}{l}\text { Grade } \\
\text { Min }\end{array}$ & 2 & 2 & 6 & 8 \\
\hline \multirow{6}{*}{ 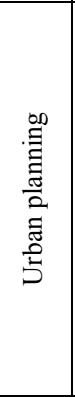 } & \multirow{6}{*}{18} & C15 & $\begin{array}{l}\text { Grade } \\
\text { Min }\end{array}$ & 1 & 3 & 10 & 8 \\
\hline & & C16 & $\begin{array}{l}\text { Grade } \\
\text { Min }\end{array}$ & 2 & 2 & 8 & 4 \\
\hline & & $\mathrm{C} 17$ & $\begin{array}{l}\text { Rating } \\
\text { Min }\end{array}$ & 0 & 0 & 0 & 0 \\
\hline & & $\mathrm{C} 18$ & $\begin{array}{c}\text { Rating } \\
\text { Min }\end{array}$ & 1 & 2 & 8 & 10 \\
\hline & & C19 & $\begin{array}{c}\text { Rating } \\
\text { Min }\end{array}$ & 4 & 4 & 8 & 4 \\
\hline & & $\mathrm{C} 20$ & $\begin{array}{l}\text { Rating } \\
\text { Min }\end{array}$ & 4 & 4 & 9 & 6 \\
\hline \multirow{10}{*}{ 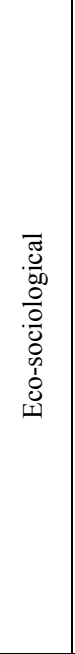 } & \multirow{10}{*}{20} & $\mathrm{C} 21$ & $\begin{array}{c}\mathrm{m} \\
\mathrm{min}\end{array}$ & 17214 & 15556 & 30467 & 26466 \\
\hline & & $\mathrm{C} 22$ & $\begin{array}{c}\text { Rating } \\
\text { Min }\end{array}$ & 1 & 3 & 10 & 8 \\
\hline & & $\mathrm{C} 23$ & $\begin{array}{l}\text { Rating } \\
\text { Min }\end{array}$ & 3 & 3 & 7 & 5 \\
\hline & & $\mathrm{C} 24$ & $\begin{array}{c}\text { Rating } \\
\text { Min }\end{array}$ & 3 & 5 & 8 & 2 \\
\hline & & $\mathrm{C} 25$ & $\begin{array}{c}\mathrm{m} \\
\max \end{array}$ & 790 & 1448 & 33884 & 40658 \\
\hline & & $\mathrm{C} 26$ & $\begin{array}{c}\text { Rating } \\
\text { Min }\end{array}$ & 2 & 3 & 8 & 6 \\
\hline & & $\mathrm{C} 27$ & $\begin{array}{c}\mathrm{m} \\
\max \end{array}$ & 9546 & 9003 & 42278 & 36705 \\
\hline & & $\mathrm{C} 28$ & $\begin{array}{l}\text { Rating } \\
\text { Min }\end{array}$ & 2 & 3 & 7 & 10 \\
\hline & & C29 & $\begin{array}{c}\text { Rating } \\
\text { Min }\end{array}$ & 2 & 4 & 8 & 6 \\
\hline & & C30 & $\begin{array}{c}\text { Rating } \\
\text { Min }\end{array}$ & 2 & 2 & 5 & 8 \\
\hline
\end{tabular}

Variants 2 and 3 have advantage over Variant 1 for connecting the Istrian railroad lines in a unitary system of Croatian railroads. Variant 3 is technically and technologically highly complex, especially in leading the route from Lupoglava to the junction on to the planned Divača - Koper railroad line with some very complex viaducts. The junction that is particularly complex is the one to the planned Divača - Koper railroad line, where a connection with a large viaduct that should then connect to the Črni Kal viaduct on the Divača - Koper railroad line is planned. The junction of a viaduct to a viaduct cannot be avoided due to the fact that there are tunnels before and after the Črni Kal viaduct.

Very demanding technical solutions and conditions of a junction to an open railroad cause exceptional investment costs which makes the economic criteria adversely evaluated, and that puts Variant 3 at a disadvantage compared to other variants.

\subsection{The choice of an optimal railroad route}

For the purpose of selecting the optimal route of the Rijeka - Koper - Trieste railroad line between the four proposed variant solutions, the values of the criteria defined in the previous chapter have been entered in the computer program "Visual PROMETHEE". Furthermore, the values of the importance of certain sets of criteria and the criteria evaluated by experts have also been included.

For the purpose of the multiple-criteria ranking of variants, two scenarios have been developed. For the first scenario, what has been used are the importance of sets of criteria and the criteria according to the model set out in Chapter 3, while the second scenario puts more emphasis on the environmental criteria. Thus, for the second scenario, higher weighting coefficients have been assigned to the group of ecological and sociological criteria so that their importance is $28 \%$. Furthermore, the economic criteria were assigned to the importance of 19 $\%$, traffic of $27 \%$, engineering of $10 \%$, and urbanplanning of $16 \%$.

\begin{tabular}{|c|l|l|r|r|r|}
\hline Rank & \multicolumn{2}{|c|}{ action } & Phi & Phĩ & Phì- \\
\hline $\mathbf{1}$ & Varijanta 1 & $\square$ & 0,4957 & 0,6082 & 0,1125 \\
\hline $\mathbf{2}$ & Varijanta 1A & $\square$ & 0,2365 & 0,4718 & 0,2353 \\
\hline $\mathbf{3}$ & Varijanta 2 & $\square$ & $-0,3093$ & 0,2513 & 0,5606 \\
\hline $\mathbf{4}$ & Varijanta 3 & $\square$ & $-0,4230$ & 0,1787 & 0,6016 \\
\hline
\end{tabular}

Figure 3 An overview of the result of Scenario 1 of the multiple-criteria analysis of the selection of the Rijeka - Koper - Trieste railroad route.

The PROMETHEE I processing method gives calculated Phi values, i.e. input $(-)$ and output $(+)$ flows or the relations of the dominance of certain pairs of actions, whereas the final achieved ranks, based on the calculation of the net value of Phi, are given by the PROMETHEE II method.

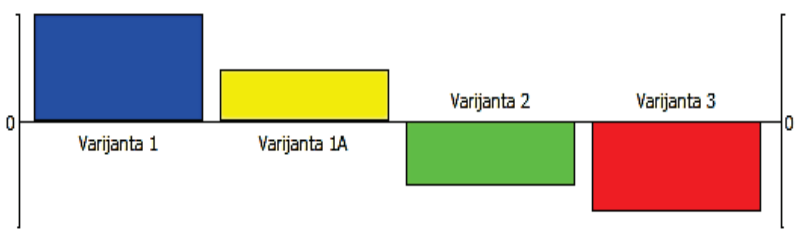

Figure 4 Overview of the Scenario 1 of the multiple-criteria analysis of the selection of the Rijeka - Koper - Trieste railroad route 
Fig. 3 shows the results of numerical processing, i.e. the values for individual variants on the basis of which their ranking was done. A graphic overview of the numerical values of net flows is shown in Fig. 4. This clearly shows the ranking of the analyzed variants: Variant 1 with a value of the net flow of 0,49 is the optimal selection, while the second place is occupied by the Variant 1A with the value of the net flow of 0,23 . Those variants absolutely dominate and are suitable for the selection of the railroad route. Variants 2 and 3 have a negative net flow and are less suitable for the selection. The final choice will depend on the decisionmaker and the goals that have been set, however, priority should be given to Variants 1 and $1 \mathrm{~A}$.

Better results shown by Variants 1 and $1 \mathrm{~A}$ are a consequence of the better rated values of urban-planning and technical-technological criteria. This is logical given the fact that the Variants 2 and 3 are technically more complex because they include large tunnel lengths, leading the route at a higher altitude, large corrections of the existing railroad lines, etc. Moreover, Variants 1 and $1 \mathrm{~A}$ require less investment resources for construction and are better assessed in terms of economic criteria.

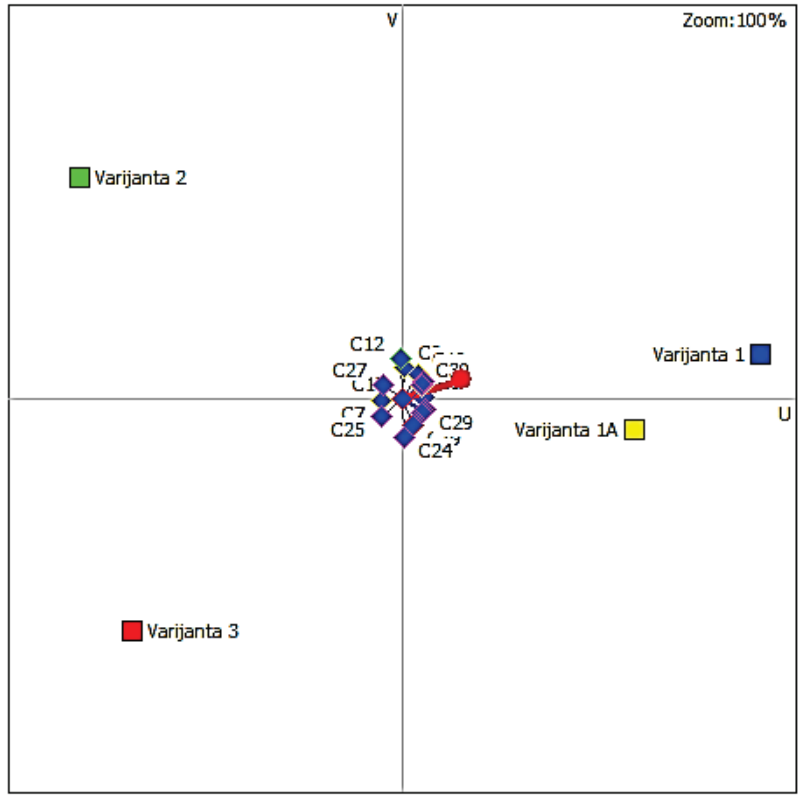

Figure 5 An overview of the results of the multiple-criteria analysis in the GAIA plane

In order to obtain a more detailed insight into the problem of choosing an alternative, a part of the computer software GAIA (Geometrical Analysis for Interactive Aid), which enables the visualization of the characteristics of a multiple-criteria problem through geometric interpretation, was used. In a two-dimensional GAIA plane, both the variants and criteria are visible, which enables a direct interpretation of a multiple-criteria analysis in a "u, $v$ " plane. The dispersion of criteria signifies their diversity in terms of numerical values, and grouping shows the similarities. The same applies for the variants: alternatives that are closer to each other are of similar numerical characteristics, and those further away are of different values.
Fig. 5 shows that the Variant 1 and Variant $1 \mathrm{~A}$ are in the same direction as the vast majority of the criteria, while other variants are in the opposite direction.

\begin{tabular}{|l|l|l|l|l|l|}
\hline $\mathbf{1}$ & Varijanta 1 & $\square$ & 0,4891 & 0,6162 & 0,1271 \\
\hline $\mathbf{2}$ & Varijanta 1A & $\square$ & 0,2346 & 0,4826 & 0,2481 \\
\hline $\mathbf{3}$ & Varijanta 2 & $\square$ & $-0,3286$ & 0,2504 & 0,5790 \\
\hline $\mathbf{4}$ & Varijanta 3 & $\square$ & $-0,3951$ & 0,2026 & 0,5977 \\
\hline
\end{tabular}

Figure 6 An overview of the results of Scenario 2 of the multiplecriteria analysis of the selection of the Rijeka - Koper - Trieste railroad route

Fig. 6 shows the results of the numerical processing for Scenario 2 which stresses the importance of the environmental criteria by giving them greater weighting coefficients. The results give the same order as the processing of Scenario 1. The obtained values of Variants 1 and 1A are nearly equal to the values of their net flow in Scenario 1. It can be seen from the results that those two variants increased their dominance even more over Variant 2, which is ranked at number three.

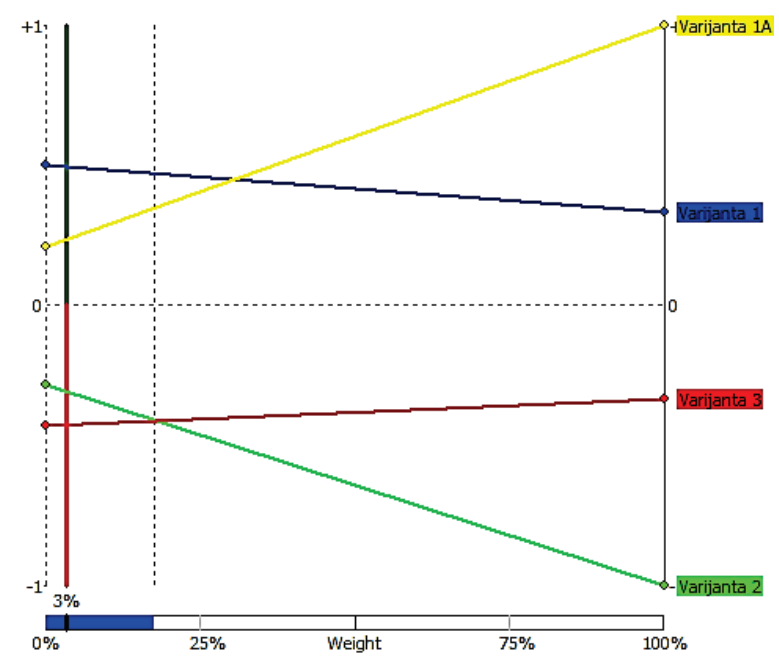

Figure 7 Sensitivity analysis of the Environmental Impact Criterion weight

Since the Scenario 2 does not influence the variant solution ranking, in Figure 6 it is shown how ranking is changed with the different weights of the environmental impact criterion. When the weight of the criterion increases, the scores of Variants $1 \mathrm{~A}$ and 3 go up, while the scores of Variant 1 and 2 decrease. The Weight Stability Interval (WSI), i.e. the weight interval within which the ranking remains unchanged, has the range from 0 to $17,5 \%$. When the weight of the environmental impact criterion exceeds $30,5 \%$, Variant $1 \mathrm{~A}$ crosses Variant 1, which comes to the second place in the multiple-criteria ranking.

\section{Conclusion}

Defining the focus groups of criteria and criteria for the evaluation and selection of the railroad route was done based on the examination and evaluation of a large number of experts who also assigned corresponding weighting coefficients to particular criteria. A model set in such a manner can be applied in practice when evaluating the appropriate railroad traffic route. 
By using the process of a multiple-criteria ranking of variants, the PROMETHEE method, what was carried out was the evaluation and selection of a railroad traffic route that will connect Rijeka, Koper, and Trieste, which proves the hypothesis posed in the introduction of this paper.

With a successful testing of the model that includes the sets of criteria and criteria for the selection of an optimal railroad route, the importance of using the multiple-criteria analysis has been confirmed. Research results prove the importance of applying the methods of the multiple-criteria analysis in decision-making for the creation of space-traffic plans and projects.

The selection of the route of the Rijeka - Koper Trieste railroad line will depend on the decision-maker; however, given the results obtained with the multiplecriteria analysis, the priority of selection should be given to Variants 1 and $1 \mathrm{~A}$.

Those mentioned variants, which begin at the Jurdani station and stretch over Ilirska Bistrica to the Pivka station and continue further over the connecting part of the railroad to Divača, are suitable for the selection of the railroad route because they show positive results, i.e. net flows. Even though Variants 2 and 3, because of the connecting of Istrian railroads into a unitary system of Croatian railroads, are more appropriate for the selection, the obtained results of the process of the multiple-criteria ranking of variants show extremely negative net flows.

The reason behind that is the fact that the mentioned variants have significantly less favourable technicaltechnological features. The construction of those routes includes greater altitudes and gradients, considerably greater lengths of facilities, and significant corrections of the existing lines. Consequently, Variants 1 and $1 \mathrm{~A}$ are also better evaluated in terms of the economic criteria as they require less financial means for the construction.

\section{References}

[1] Kosijer, M.; Ivić, M.; Marković, M.; Belošević, I. Multicriteria decision-making in railway route planning and design. // Građevinar. 64, 3(2012), pp. 195-205.

[2] Krpan, Lj.; Maršanić, R.; Mamić, M. Moguće primjene postupka višekriterijske optimizacije u prometnom planiranju i projektiranju. // Skup o prometnim sustavimaautomatizacija u prometu 2012, Korema, 2012, pp. 13-18.

[3] Vilke, S.; Baričević, H.; Maglić, L. Kriteriji za vrednovanje kopnene prometne trase. // Suvremeni promet: časopis za pitanja teorije i prakse prometa. 33, 5-6 (2013), pp. 422430.

[4] Roubens, M. Preference relations on actions and criteria in multi-criteria decision making. // European Journal of Operational Research. 10, (1982), pp. 51-55. https://doi.org/10.1016/0377-2217(82)90131-X

[5] Nikolić, I.; Borović, S. Višekriterijumska optimizacija: metode, primena u logistici, softver, Centar vojnih škola VJ, Beograd, 1996.

[6] Karleuša, B.; Deluka-Tibljaš, A.; Benigar, M. Mogućnosti primjene postupaka višekriterijske optimizacije $u$ prometnom planiranju i projektiranju. // Suvremeni promet. 23, 1-2(2003), pp. 104-107.

[7] Brans, J. P.; Vincke, B.; Mareschal, B. How to Select and How to Rank Project: The PROMETHEE Method. // European Journal of Operational Research. 24, (1986), pp. 207-218. https://doi.org/10.1016/0377-2217(86)90044-5

[8] Brans, J. P.; Mareschal, B.; Vincke, P. PROMETHEE - A New Family of Outranking Methods in Multicriterial
Analysis, Operational Research, '84, North Hollan, Amsterdam, 1984, pp. 477-490.

[9] Prostorno i prometno integralna studija Primorsko-goranske županije i Grada Rijeke - prethodna studija opravdanosti, Institut IGH d.d., Rijeka - Zagreb, 2010

[10] Studija okvirnih mogućnosti povezivanja sustava sjevernojadranskih luka željezničkom prugom visoke učinkovitosti, Institut IGH d.d., Zagreb, 2014.

\section{Authors' addresses}

Ljudevit Krpan

Primorje-Gorski kotar County

Adamićeva 10, 51000 Rijeka, Croatia

ljudevit.krpan@pgz.hr

Siniša Vilke

The Faculty of Maritime Studies of the University of Rijeka Studentska ul. 2, 51000 Rijeka, Croatia

svilke@pfri.hr

\section{Marin Milković}

University North

Trg dr. Žarka Dolinara 1, 48000 Koprivnica, Croatia

marin.milkovic@unin.hr 